\title{
Novel Integrative Options for Passive Filter Inductor in High Speed AC Drives
}

\author{
M. Raza Khowja, C. Gerada, G. Vakil, P. Wheeler and C. Patel \\ Power Electronics, Machines and Control (PEMC) Group \\ The University of Nottingham, Nottingham, UK \\ The University of Nottingham, Ningbo, China
}

\begin{abstract}
This paper presents novel integration options for passive inductor which include: motor-shaped rotational and motor-shaped rotor-less inductor for high speed motor drive system. The novel options have been designed and their performance is compared with the conventional $\mathrm{EE}$ core inductor using finite element analysis. It is observed that there is a significant reduction in total losses at fundamental frequency along with substantial reduction in the $\mathrm{AC}$ copper loss at 10,15 and $20 \mathrm{kHz}$ switching frequencies, when the proposed integrated options are utilized. For the motor-shaped rotational inductor, the total losses at fundamental frequency and $\mathrm{AC}$ copper loss at different switching frequencies are reduced by $26.1 \%$ and $73.8 \%$ (at different switching frequencies) respectively. There is a reduction in overall volume by $3.6 \%$, but this comes with $11.7 \%$ increase in weight. For the motor-shaped rotor-less inductor, the total losses at fundamental frequency and AC copper loss at different switching frequencies are reduced by $10.4 \%$ and $73.8 \%$ (at different switching frequencies) respectively. There is a reduction in overall volume by $3.6 \%$ but this comes with $6.1 \%$ increase in weight. The proposed designs can share the cooling system of the motor thus, eliminating the requirement of separate cooling system.
\end{abstract}

Index Terms - EE Core Inductor, Integrated Inductors, Integration of Passives, Rotational Inductors and Rotor-less Inductor and Motor-Shaped Inductors.

\section{INTRODUCTION}

$\mathrm{T}$ HE passive components associated with drive systems such as capacitors, inductors or transformers occupy a significant amount of space and have added penalties of potential higher weight and losses. Traditionally filters are designed and introduced after the drive system components have been defined which results in a discrete sub-system. The integrated drives have been a focus of research in power electronics industry and have proven to be successful [1].

There are many possibilities in a drive system to integrate the passive elements. The use of integration technologies in drive allows integrating drive functions of two or more parts into one part that results in compact design, reduction in cost, mass and size and fewer manufacturing processes. Therefore, applications where high energy or power density is needed, the use of the integrated options present to be the best solution.

In this paper two novel options for integrating passive filter inductors, such as - motor-shaped rotational inductor and motor-shaped rotor-less inductor, for high speed drive applications are proposed. Both designs are modelled and analyzed through finite element analysis (FEA), and compared with conventional EE core inductor.

\section{LITERATURE REVIEW}

\section{A. Conventional Filter Inductors}

The conventional designs for the filter inductor are presented in this section. Different type of cores has been used for manufacturing inductors. This include: tape wound, powder and laminated cores [2].
C Core

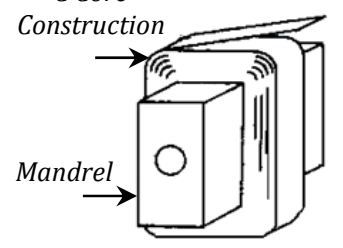

(c)

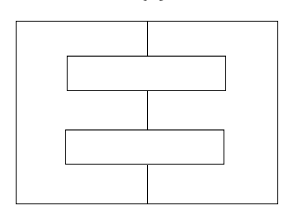

(e)
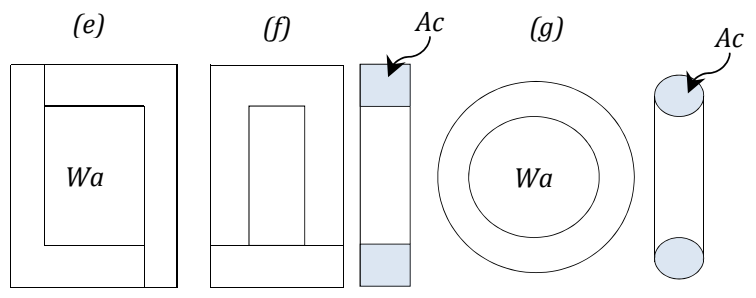

Fig. 1: Construction of Conventional Inductors (a) $\mathrm{C}$ core (b) Toroidal Core (c) EE core (d) EI core (e) LL core (f) UI core (g) Toroidal Core

Air core does not use the magnetic core. The coils are wound on non-magnetic forms such as plastic or ceramic. The drawback of air-cored inductor is that they are less permeable in nature than magnetic core but are often used in high frequency applications as they are free from any core losses that depend on frequency squared [2-4].

Tape wound cores are constructed by winding around a mandrel, a magnetic material in the form of preslit tape as 
shown in Fig. 1(a) and (b). The benefit of using this type of core is that flux is parallel with the direction of rolling magnetic material that provides the full utilization of flux with the minimum field strength. Tape wound core can be $\mathrm{C}$, EE or toroid in construction [2].

Powder cores are very unique as they have built-in small airgap, evenly distributed throughout the core material. This acts in a similar way as a core with airgap which reduces the core saturation at higher levels of current. They come in a variety of materials and are very stable with temperature. They can be toroid, EI or EE in construction [2].

The laminated cores are one of the most commonly used cores in power electronics and drive applications. Laminated core consists of punched steel sheets with an insulating coating on the surface. The insulation coating reduces the eddy currents between the sheets. The laminated cores can also be EE, EI, LL, UI and toroid in construction as shown in Fig. 1(c)-(g) [2].

\section{B. Integrated Filter Inductors}

In recent times, the passive integration has been focused in power electronics and drive application that has resulted in an overall compact and power dense system. In [5-8], the perspectives on the integrated filter inductors are presented, that motivates the drive integration on a system level. The design of integrated filter inductor for power factor correction application is presented in [5]. The paper modified the stator laminations to increase the stator back iron which act as an integrated filter inductor. This modification increases the outer diameter of the motor.

The complete stator back iron is used as magnetic component for one or more discrete inductors by integrating toroidal winding which drives alternating magnetic flux in the complete loops through the back iron of the stator core. If the stator back iron of the machine is operating in linear region then the presence of ring flux due to inductor winding will not affect the main machine flux [6-7].

The principle of electromagnetic integration is used for integrating capacitor in the same magnetic component as that of the inductor. "The integrated filter is the planar integrated L-C winding, which consists of a dielectric substrate with conductor windings directly deposited on both sides, thus resulting in a distributed inductance and capacitance structure. Moreover, different equivalent circuits have been achieved by connecting the terminals of integrated LC structure in an appropriate manner" [8-14].

The same principle of [8-14] is applied for C-core EMI inductor in [15-16]. "The distributed capacitance is implemented in the conventional way, whereas the inductor is implemented by utilizing the cathode and anode foils of the capacitor to form the windings. The windings are then enclosed in a can, which has a hole in the middle for the magnetic core".

\section{NOVEl INTEGRATIVE OPTIONS For PASSIVE INDUCTOR}

The two proposed options for integrating passive inductors in power electronics and drive applications are presented and analyzed in detail. They are,

1. Motor-shaped rotational inductor and,

2. Motor-shaped rotor-less inductor.

The motor-shaped integrated inductor is shown in Fig. 2. The motor-shaped rotational inductor design is extensively different from conventional inductors. It has stator and rotor like conventional motor or generator but without any magnet, winding or saliency on rotor. This motor like shape allows the inductor to integrate within the motor or generator by mounting the inductor rotor on the same shaft. Furthermore, inductor stator can share the same motor housing thus eliminating the requirement of separate cooling system. As the motor-shaped inductor uses the same cooling system as that of motor or generator, it can be operated with a higher current density that would result in to reduced overall size and weight of the inductor.

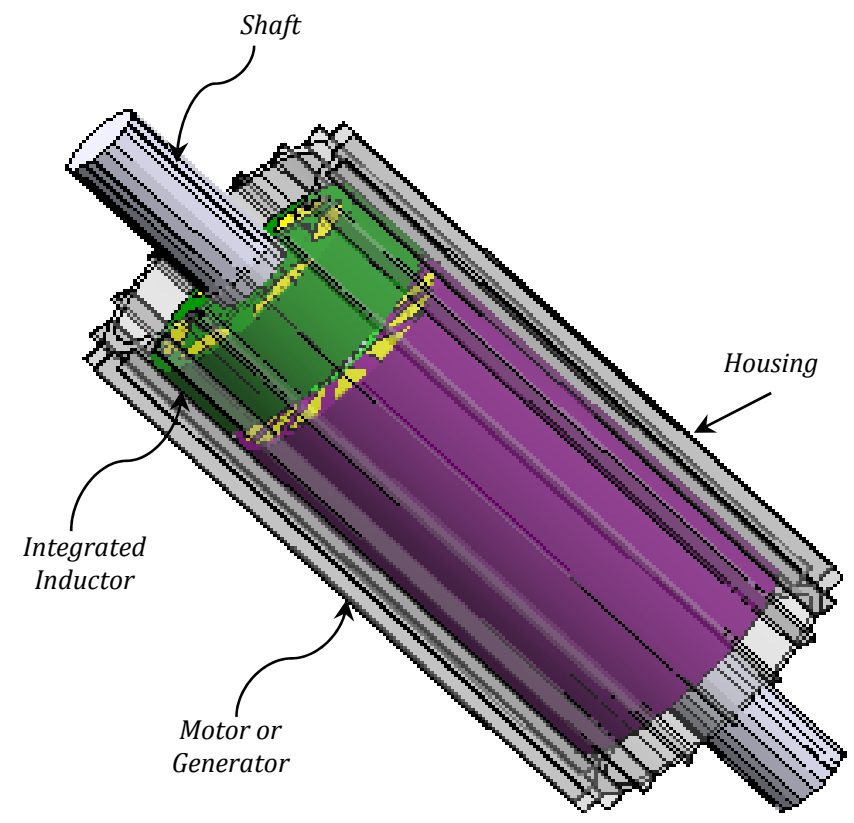

Fig. 2: Axial View of Integrated Motor-shaped Inductor

Secondly, rotor iron losses of the motor-shaped inductor can be minimized if the rotor is rotating with the motor shaft because the fundamental iron losses in the rotor will be eliminated as it is rotating at synchronous speed. This design is more suitable for high power applications where fundamental losses become more dominant than the losses due to PWM switching. Furthermore, the design of the motorshaped inductor can be optimized by varying the slot opening, slot opening height, teeth width, teeth height etc.

The motor-shaped rotor-less inductor has the same structure as the motor-shaped rotational inductor but with no rotor. This design can also be integrated with the motor or generator by placing it axially inside the same housing. This design is suitable solution for high power line inductors or isolation transformers where supply frequency is fixed and cooling requirement is high. The motor-shaped rotor-less 
design is also fit to use for power transformer applications, where the transformer can be integrated with the generator drive.

\section{A. Finite Element Validation of Rotational Inductor}

To validate the concept of the rotational inductor, a finite element (FE) model was made in Infolytica MagNet software. The inductor design as shown in Fig. 4(b) is considered when the rotor is rotating and standstill.

The $\mathrm{X}$ and $\mathrm{Y}$ components of magnetic flux density in the rotor at one point are evaluated for both static and rotating rotor. The $\mathrm{X}$ and $\mathrm{Y}$ components of magnetic flux density are then converted into the $\mathrm{d}-\mathrm{q}$ reference frame. As the $\mathrm{q}$ component of the rotor flux density is zero, only the $\mathrm{d}$ component of the rotor flux density is shown in Fig. 3.

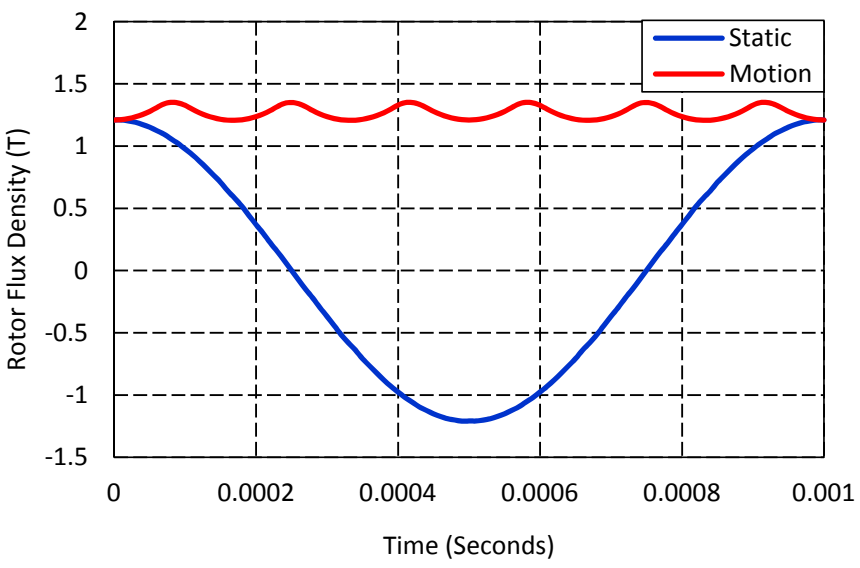

Fig. 3: d-component of flux Density for Static and Rotating Rotor

It can be seen that the flux density in the rotor is not rotating but stationary when the rotor rotates at synchronous speed, and hence minimizes the iron losses in the rotor. However, it contains harmonics due to slotting of the stator. On the other hand, the flux density is varying sinusoidally when the rotor is not rotating. The corresponding iron losses of the considered inductor design are shown in Table I. It is worth noting that both frequency dependent iron loss components have been reduced drastically in the rotor.

There is reduction in the losses by $78.2 \%$ for the rotating rotor compared to the stationary rotor. However, a small amount of iron loss is still present due to the slotting effect of the stator windings and the non-uniform distribution of magnetic field in the rotor.

\section{B. Comparative Analysis}

In this section, both motor-shaped rotational and rotor-less inductors are compared with the conventional EE core inductor. The 2D cross sections for each of the designed inductors and their respective flux density distribution are shown in Fig 4(a)-(c) and Fig. 5(a)-(c). EE core inductor is designed, using area-product approach, at first and considered as a bench mark for comparison [2,17].

The performance comparison in terms of iron losses, AC copper loss, core weight and overall volume, is presented in Table II, III and IV. For the purpose of fair comparison, the type of core material, synchronous inductance, operating flux density, fundamental frequency, switching frequency, turns per phase, slot fill factor, window area and conductor diameter are kept the same, the details of which are provided in Table V.

TABLE I: Rotor IRON LOSSES WHEN ROTOR IS STATIC AND ROTARY

\begin{tabular}{|c|c|c|c|}
\hline PARAMETERS & Static & Motion & Unit \\
\hline $\begin{array}{c}\text { Hysteresis } \\
\text { Loss }\end{array}$ & 17.4 & 1.33 & $\mathrm{~W}$ \\
\hline $\begin{array}{c}\text { Eddy Current } \\
\text { Loss }\end{array}$ & 33.6 & 9.77 & $\mathrm{~W}$ \\
\hline $\begin{array}{c}\text { Total } \\
\text { Losses }\end{array}$ & 51 & 11.1 & $\mathrm{~W}$ \\
\hline $\begin{array}{c}\text { Loss } \\
\text { Reduction }\end{array}$ & - & 78.2 & $\%$ \\
\hline
\end{tabular}

Initially, the DC copper loss without end windings and the inductor stack length were kept the same for the EE core inductor and motor-shaped inductor. The inductance was found higher for motor-shaped inductor compared to the EE core inductor, therefore, the stack length was reduced to $65 \mathrm{~mm}$ to keep the synchronous inductance same for all inductor designs.

To evaluate the AC copper loss at fundamental frequency and switching frequency (FSW), solid conductors were made as shown in Fig. 4(a)-(c). The magnitude of the harmonic component is considered to be $5 \%$ of the fundamental for determining and analyzing the AC copper loss. The fundamental current with switching frequency components were injected into the FEA model. The injected current waveforms are shown in Fig. 6(a)-(c). The relation between the $\mathrm{DC}$ and $\mathrm{AC}$ copper loss is given by,

$$
P_{\text {copper }}=P_{d c}+P_{a c}
$$

where,

$P_{\text {copper }}$ is the total copper losses,

$P_{d c} \quad$ is the DC copper loss with end winding effect taking into account and

$P_{a c} \quad$ is the AC copper loss due to skin and proximity effect where end winding AC copper loss effect is neglected.

The AC copper loss in the EE core inductor is greater than that of motor-shaped inductors at all switching frequencies, and is shown in Table III. This is because most conductors are accommodated near to the airgap in EE design, due to the limited fill factor, whereas conductors in the motor-shaped inductors are far from the slot opening airgap. Thus, the conductors in the EE design experience more airgap fringing flux compared to motor-shaped inductors.

The leakage flux is lower in the motor-shaped inductor as its window width is wider than the EE core inductor. The effect of fringing and leakage fluxes will result in more flux cutting the conductors thus increasing the $\mathrm{AC}$ resistance, and hence, AC copper loss at both fundamental and switching frequencies. 


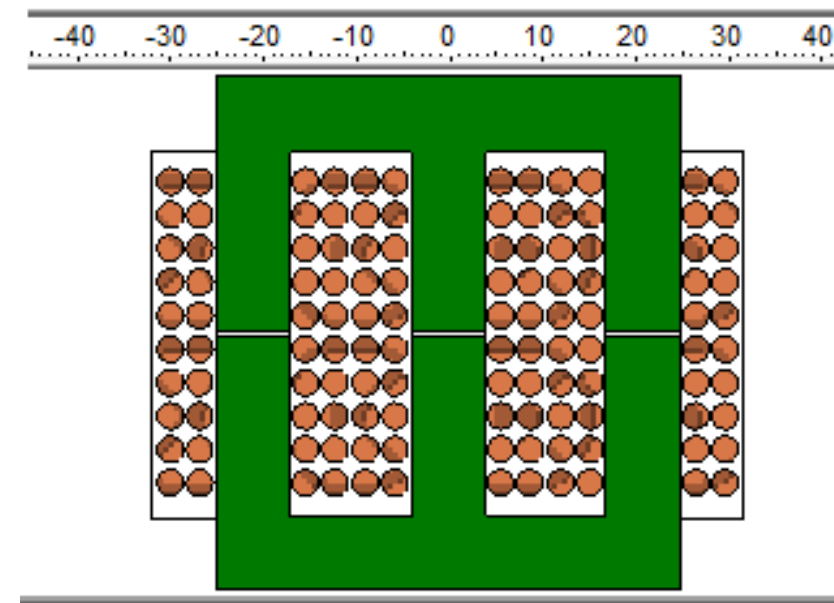

$40, \ldots$

\begin{tabular}{llllllllll}
\hline-40 & -30 & -20 & -10 & 0 & 10 & 20 & 30 & 40 \\
\hline
\end{tabular}

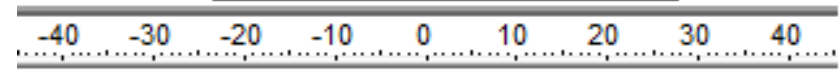

a) EE Core
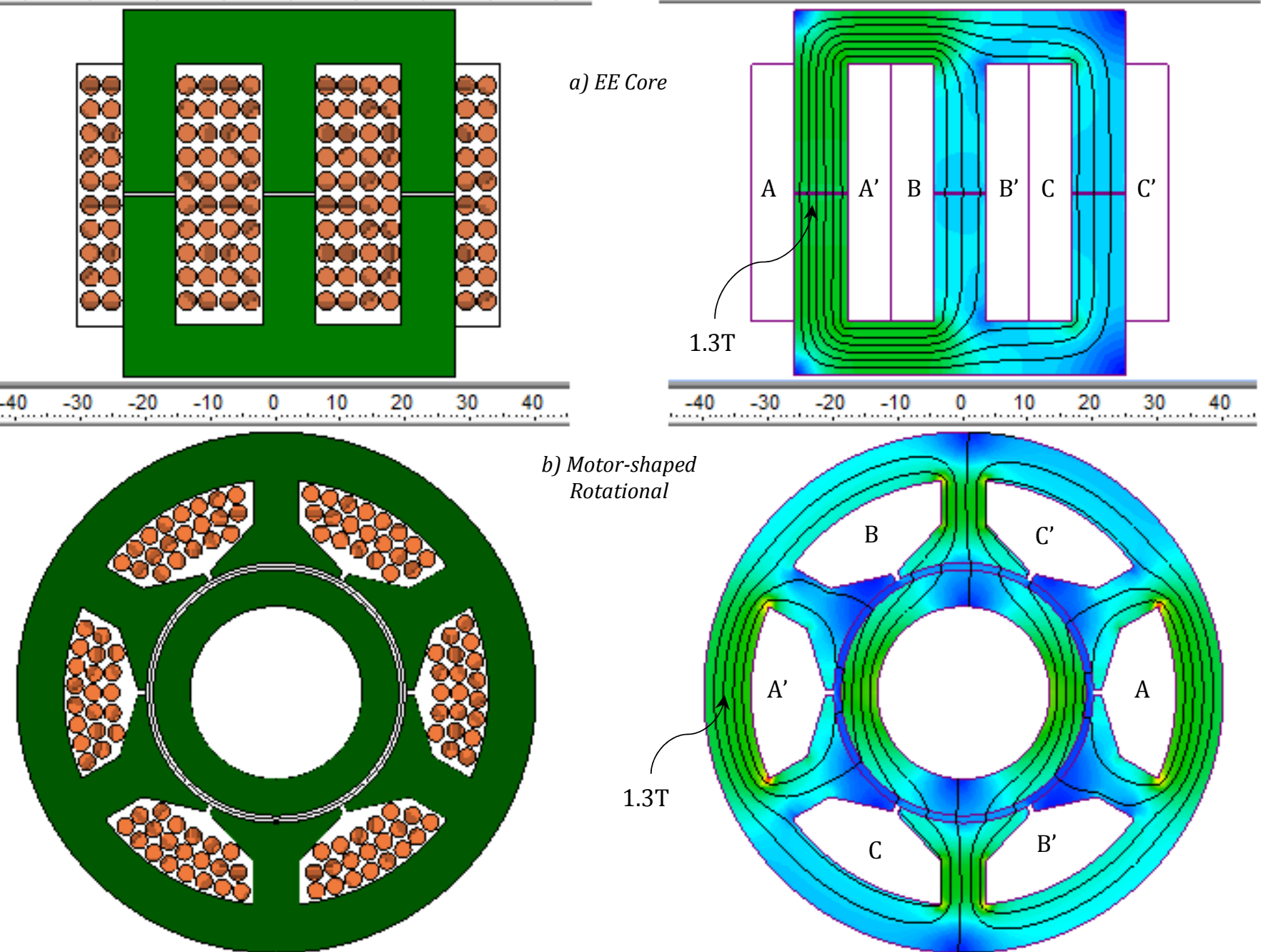

b) Motor-shaped

Rotational

\begin{tabular}{lllllllll}
\hline-40 & -30 & -20 & -10 & 0 & 10 & 20 & 30 & 40 \\
\hline
\end{tabular}
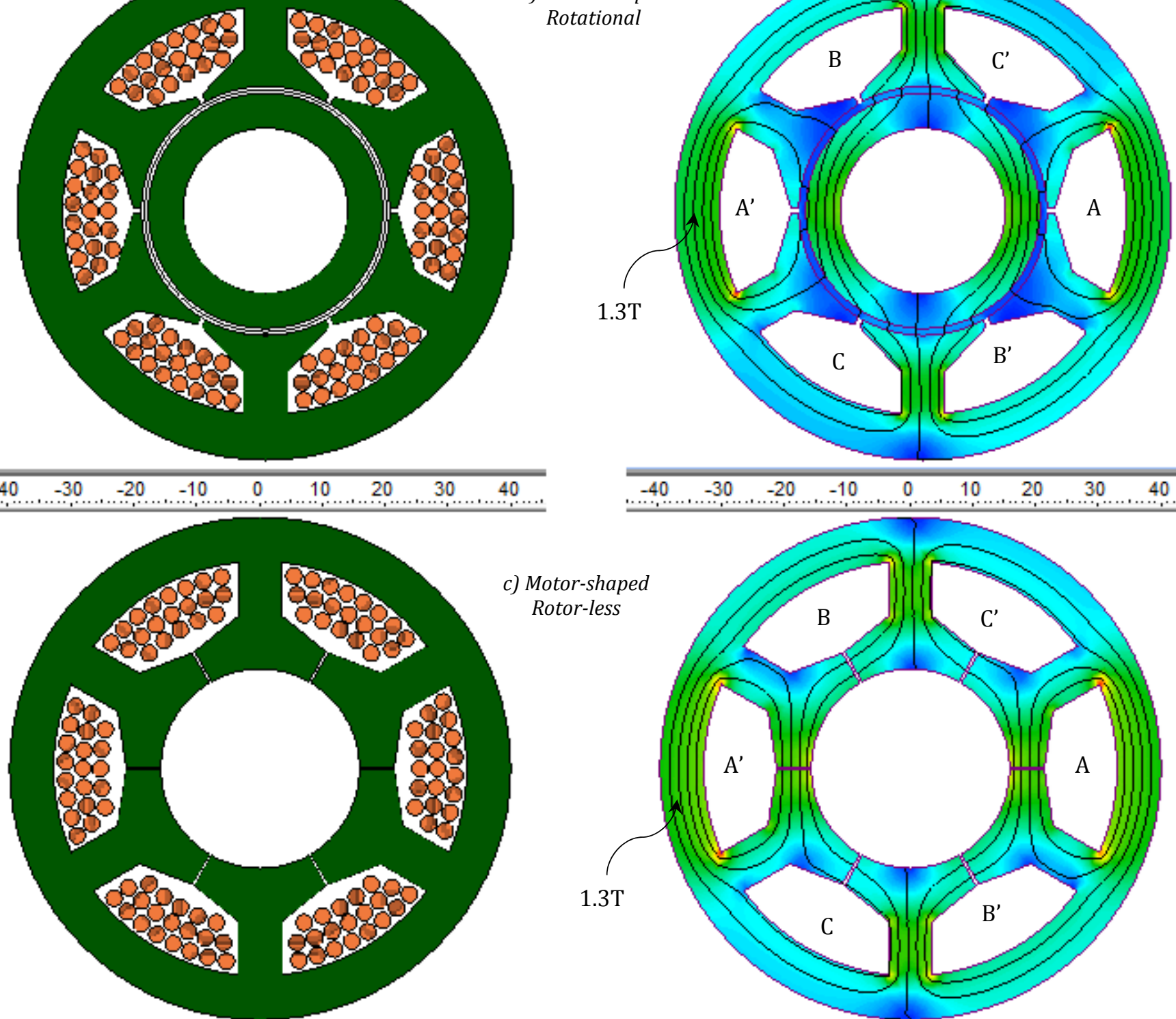

c) Motor-shaped

Rotor-less

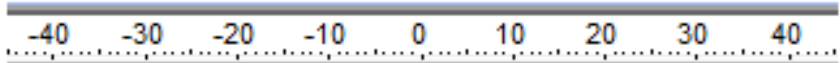

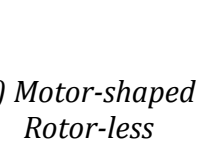

Fig. 4: Cross Section of the Designed Inductors (a) EE core Inductor (b) Motor-shaped Rotational Inductor and (c) Motor-shaped Rotor-less Inductor

Fig. 5: Flux Distribution of the Designed Inductors (a) EE core Inductor (b) Motor-shaped Rotational Inductor and (c) Motor-shaped Rotor-less Inductor 


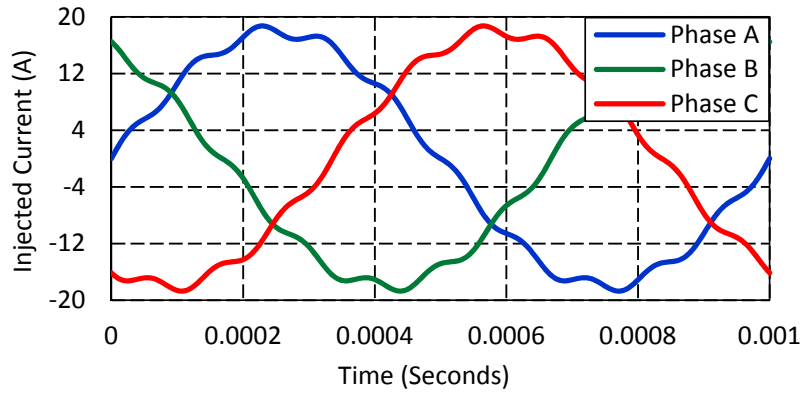

(a) Injected current with $10 \mathrm{kHz}$ switching component

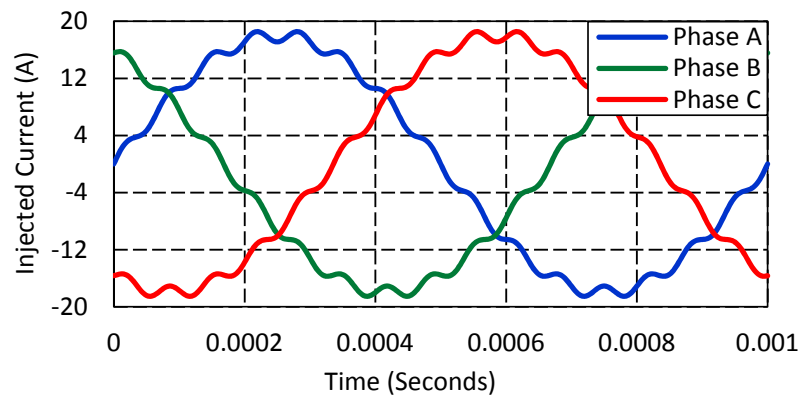

(b) Injected current with $15 \mathrm{kHz}$ switching component

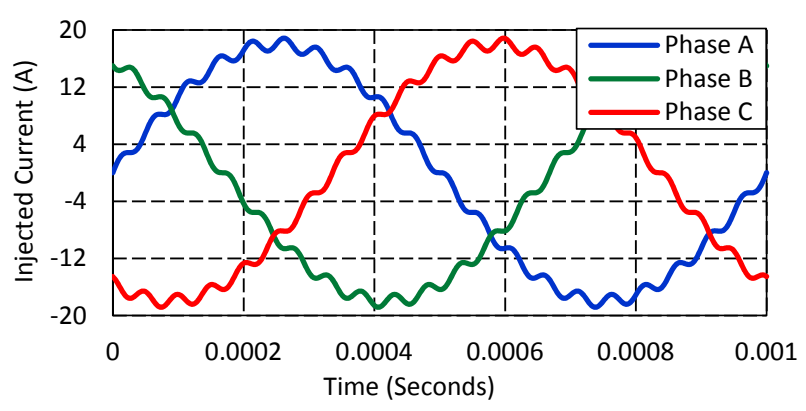

(c) Injected current with $20 \mathrm{kHz}$ switching component

Fig. 6: Injected current with switching frequency components

From Tables II, III and IV, it can be seen that both proposed designs contribute better in terms of iron losses, $\mathrm{AC}$ copper loss and overall volume as compared to conventional EE core inductor. The iron losses in motor-shaped rotational inductor design are reduced by $22.5 \%$ and the copper losses at fundamental frequency is reduced by $45.3 \%$. The total losses at fundamental frequency are reduced by $26.1 \%$ when compared to conventional EE core inductor. Also, there is a reduction in overall volume of $3.6 \%$. The iron losses in motorshaped rotor-less inductor design are reduced by $3.9 \%$ and the copper losses at fundamental frequency is reduced by $45.3 \%$. The total losses at fundamental frequency are reduced by $10.4 \%$ when compared to conventional EE core inductor. Also, there is a reduction in overall volume of $3.6 \%$.

On the other hand, AC copper loss at switching frequencies of 10,15 and $20 \mathrm{kHz}$ is reduced drastically by $73.8 \%$ in motor-shaped rotational and rotor-less inductor when compared to conventional EE inductor. Furthermore, the motor-shaped inductor does not require any additional cooling system since it is integrated inside the same motor or generator housing. However, the EE core inductor design is slightly better in terms of weight but the motor-shaped inductors provides better utilization of space and higher possibility of integration.

TABLE II: COMPARATIVE ANALYSIS OF INTEGRATED AND EE INDUCTOR

\begin{tabular}{|c|c|c|c|c|}
\hline PARAMETERS & $\begin{array}{c}\mathrm{EE} \\
\text { Inductor }\end{array}$ & $\begin{array}{c}\text { Motor-shaped } \\
\text { Rotational } \\
\text { Inductor }\end{array}$ & $\begin{array}{c}\text { Motor-shaped } \\
\text { Rotor-less } \\
\text { Inductor }\end{array}$ & Unit \\
\hline $\begin{array}{c}\text { Iron } \\
\text { Losses } \\
\end{array}$ & 142.2 & 110.2 & 136.7 & W \\
\hline $\begin{array}{c}\text { DC Copper } \\
\text { Loss } \\
\end{array}$ & 9.2 & 9.7 & 9.7 & W \\
\hline $\begin{array}{l}\text { AC Copper } \\
\text { Loss }\end{array}$ & 17.46 & 4.89 & 4.89 & W \\
\hline $\begin{array}{l}\text { Total Copper } \\
\text { Losses }\end{array}$ & 26.66 & 14.59 & 14.59 & W \\
\hline $\begin{array}{c}\text { Total Inductor } \\
\text { Losses }\end{array}$ & 168.86 & 124.79 & 151.29 & W \\
\hline $\begin{array}{c}\text { Iron Core } \\
\text { Weight }\end{array}$ & 1.3 & 1.51 & 1.39 & $\mathrm{Kg}$ \\
\hline $\begin{array}{l}\text { Copper } \\
\text { Weight } \\
\end{array}$ & 0.826 & 0.871 & 0.871 & $\mathrm{Kg}$ \\
\hline $\begin{array}{c}\text { Total Inductor } \\
\text { Weight }\end{array}$ & 2.13 & 2.38 & 2.26 & $\mathrm{Kg}$ \\
\hline $\begin{array}{c}\text { Overall Inductor } \\
\text { Volume }\end{array}$ & 338.7 & 326.56 & 326.56 & $\mathrm{~cm}^{3}$ \\
\hline $\begin{array}{c}\text { Stack } \\
\text { Length }\end{array}$ & 115 & 65 & 65 & $\mathrm{~mm}$ \\
\hline $\begin{array}{l}\text { Airgap } \\
\text { Length }\end{array}$ & 0.35 & 1.1 & 0.4 & $\mathrm{~mm}$ \\
\hline
\end{tabular}

TABLE III: AC COPPER LOSS AT DifFERENT SWITCHING FREQUENCIES

\begin{tabular}{|c|c|c|c|c|}
\hline FSW & $\begin{array}{c}\text { EE } \\
\text { Inductor }\end{array}$ & $\begin{array}{c}\text { Motor-shaped } \\
\text { Rotational Inductor }\end{array}$ & $\begin{array}{c}\text { Motor-shaped } \\
\text { Rotor-less Inductor }\end{array}$ & Unit \\
\hline $\begin{array}{c}10 \\
\mathrm{kHz}\end{array}$ & 1.42 & 0.37 & 0.37 & $\mathrm{~W}$ \\
\hline $\begin{array}{c}15 \\
\mathrm{kHz}\end{array}$ & 1.98 & 0.52 & 0.52 & $\mathrm{~W}$ \\
\hline $\begin{array}{c}20 \\
\mathrm{kHz}\end{array}$ & 2.47 & 0.65 & 0.65 & $\mathrm{~W}$ \\
\hline
\end{tabular}

TABLE IV: PERFoRMANCE COMPARISON OF INTEGRATED AND EE CORE INDUCTOR

\begin{tabular}{|c|c|c|c|}
\hline PARAMETERS & $\begin{array}{c}\text { EE } \\
\text { Inductor }\end{array}$ & $\begin{array}{c}\text { Motor-shaped } \\
\text { Rotational } \\
\text { Inductor }\end{array}$ & $\begin{array}{c}\text { Motor-shaped } \\
\text { Rotor-less } \\
\text { Inductor }\end{array}$ \\
\hline $\begin{array}{c}\text { \% Iron Loss } \\
\text { Reduction }\end{array}$ & 0 & 22.5 & 3.9 \\
\hline $\begin{array}{c}\text { \% Copper Losses } \\
\text { Reduction }\end{array}$ & 0 & 45.3 & 45.3 \\
\hline $\begin{array}{c}\text { \% Total Losses } \\
\text { Reduction }\end{array}$ & 0 & 26.1 & 10.4 \\
\hline $\begin{array}{c}\text { \% Increase } \\
\text { in Weight }\end{array}$ & 0 & 11.7 & 6.1 \\
\hline $\begin{array}{c}\text { \% Volume } \\
\text { Reduction }\end{array}$ & 0 & 3.6 & 73.8 \\
\hline $\begin{array}{c}\text { \% AC Loss } \\
\text { Reduction @ } 10,15 \\
\text { \&20kHz }\end{array}$ & 0 & 73.8 & No \\
\hline $\begin{array}{c}\text { Additional } \\
\text { Cooling Required }\end{array}$ & Yes & No & Yes \\
\hline $\begin{array}{c}\text { Integration } \\
\text { Possible }\end{array}$ & No & Yes & \\
\hline
\end{tabular}


TABLE V: INDUCTOR DESIGN SPECIFICATIONS

\begin{tabular}{|c|c|c|}
\hline SPECIFICATIONS & VALUES & UNIT \\
\hline Magnetic Material & $\begin{array}{c}\text { Non Oriented Steel } \\
\mathrm{M}-1529 \mathrm{Ga}\end{array}$ & - \\
\hline Required Inductance & 1.3 & $\mathrm{mH}$ \\
\hline Operating Current & 18 & $\mathrm{~A}$ \\
\hline Operating Frequency & 1000 & $\mathrm{~Hz}$ \\
\hline Switching Frequency & $10,15 \& 20$ & $\mathrm{kHz}$ \\
\hline Turns per phase & 20 & - \\
\hline Slot Fill Factor & 0.49 & $\mathrm{~mm}-\mathrm{sq}$ \\
\hline Window Area & $2 \times 212$ & $\mathrm{~mm}$ \\
\hline Conductor Diameter & 2.6 & $\mathrm{~A} / \mathrm{mm}$ \\
\hline RMS Current Density & 2.36 & $\mathrm{~mm}$ \\
\hline $\begin{array}{c}\text { Motor-shaped Inductor } \\
\text { Shaft Diameter }\end{array}$ & 27 & \\
\hline
\end{tabular}

\section{CONCLUSIONS}

Two novel inductor integrated options are proposed and analyzed in this paper. These options include: motor-shaped rotational inductor and motor-shaped rotor-less inductor. The comparative analysis between traditional and motor-shaped inductors has shown a significant reduction in iron and ac copper resistance. The total losses in motor-shaped rotational inductor at fundamental frequency and $\mathrm{AC}$ copper loss at different switching frequencies were reduced by $26.1 \%$ and $73.8 \%$ respectively at the expense of $11.7 \%$ increase in weight. Also, there is a reduction in overall volume of 3.6\%. The total losses in motor-shaped rotor-less inductor at fundamental frequency and $\mathrm{AC}$ copper loss at different switching frequencies were reduced by $10.4 \%$ and $73.8 \%$ respectively. However, this comes at the expense of $6.1 \%$ increase in weight. Also, there is a reduction in overall volume of $3.6 \%$.

Furthermore, the proposed designs can share the same motor cooling thus eliminating the need for the separate cooling system. The motor-shaped designs are integrated in the same housing which permits us to design the inductor with higher losses. The design with higher current density will reduce the overall size and weight of the inductor.

In terms of applications, the rotational inductor design can be used for inverter output filters and the rotor-less design is more suitable for high power line inductors or isolation transformers. Finite element validation of this concept along with the detailed performance comparison has been presented in this paper.

\section{REFERENCES}

[1] Robert Abebe, Gaurang Vakil, Giovanni Lo Calzo, Thmas Cox, Simon Lambert, Mark Johnson, Chris Gerada, Barrie Mecrow "Integrated motor drives: state of the art and future trends" IET Electric Power Applications, 15 pp, Print ISSN 1751-8660, Online ISSN 1751-8679

[2] Colonel Wm. T. Mclyman "Transformer and Inductor Design Handbook", Fourth Edition

[3] Naayagi R.T, Forsyth A.J. "Design of high frequency air-core inductor for DAB converter" Power Electronics, Drives and Energy Systems (PEDES), 2012 IEEE International Conference. Publication Year: 2012, Page(s): 1 - 4

[4] Meere R, Ningning Wang, O'Donnell T, Kulkarni S, Roy S, O'Mathuna, S.C. "Magnetic-Core and Air-Core Inductors on Silicon: A
PerformanceComparison up to $100 \mathrm{MHz}$ " Magnetics, IEEE Transactions. Publication Year: 2011 , Page(s): 4429 - 4432

[5] Nee B.M, Chapman P.L. "Integrated Filter Element in Electric Drives" Vehicle Power and Propulsion Conference, 2007. VPPC 2007. IEEE. Publication Year: 2007, Page(s): 148 - 153

[6] Garvey S.D. Norris, W.T, Wright M.T. "The role of integrated components in protecting motor windings". Electric Power Applications, IEEE Proceedings - Volume: 147 , Issue: 5 Publication Year: 2000, Page(s): 367 - 370

[7] Nakajima, Yuki Imazu, Tomoya Mizukoshi, Yukio Sato, Sho Zushi, Yusuke "Integrated Capacitor Type Stator", Patent No. 8049383

[8] Chen R, van Wyk J.D, Wang S, Odendaal W.G. "Planar electromagnetic integration technologies for integrated EMI filters". Industry Applications Conference, 2003. 38th IAS Annual Meeting. Conference Record of the Volume: 3. Publication Year: 2003, Page(s): 1582 - 1588 vol.3

[9] Fang Luo, Robutel R, Shuo Wang, Wang F, Boroyevich D. "Integrated Input EMI Filter for a $2 \mathrm{~kW}$ DC-fed 3-phase Motor Drive". Applied Power Electronics Conference and Exposition, 2009. APEC 2009. Twenty-Fourth Annual IEEE. Publication Year: 2009, Page(s): $325-$ 329

[10] Chen R, Shuo Wang, van Wyk J.D, Odendaal W.G. "Integration of EMI filter for distributed power system (DPS) front-end converter" Power Electronics Specialist Conference, 2003. PESC '03. 2003 IEEE 34th Annual Volume: 1 Publication Year: 2003, Page(s): $296-300$ vol. 1

[11] Zhao L, Strydom J.T, van Wyk J.D. "Wide band modelling of integrated passive structure: the series resonator". Power Electronics Specialists Conference, 2002. pesc 02. 2002 IEEE 33rd Annual Volume:3. Publication Year: 2002 , Page(s): 1283 - 1288 vol.3

[12] Lingyin Zhao Strydom J.T, van Wyk J.D. "An alternative planar multicell structure integrated reactive module" Industry Applications Conference, 2001. Thirty-Sixth IAS Annual Meeting. Conference Record of the 2001 IEEE Volume: 4 Publication Year: 2001, Page(s): 2217 - 2223 vol.4

[13] Chen R, Strydom J.T, van Wyk J.D. "Design of planar integrated passive module for zero-voltage switched asymmetrical half bridge PWM converter" Industry Applications, IEEE Transactions on Volume: 39, Publication Year: 2003 , Page(s): 1648 - 1655

[14] Strydom J.T, van Wyk J.D, Ferreira J.A. "Some limits of integrated LCT modules for resonant converters at $1 \mathrm{MHz}$ " Industry Applications Conference, 1999. Thirty-Fourth IAS Annual Meeting. Conference Record of the 1999 IEEE. Publication Year: 1999, Page(s): 1411 - 1417 vol.2

[15] Popovic-Gerber Jelena, Gerber M, Ferreira Braham "Integrated filter in electrolytic capacitor technology for implementation in high power density idustrial drives" Power Electronics Specialists Conference, 2008. PESC 2008. IEEE. Publication Year: 2008, Page(s): 2968 - 2974

[16] Popovic J, Ferreira J.A, Gerber M.B, Konig A, de Doncker, R. "Integration technologies for high power density power electronic converters for AC drives". Power Electronics, Electrical Drives, Automation and Motion, 2006. SPEEDAM 2006. Publication Year: 2006, Page(s): 634 - 639

[17] Kazimierczuk M.K, Sekiya H. "Design of AC resonant inductors using area product method" Energy Conversion Congress and Exposition, 2009. ECCE 2009. IEEE Publication Year: 2009 